\title{
Yield, resource use efficiency and trace metal uptake of weeping lovegrass grown on municipal sludge-amended soil
}

Running title: Municipal sludge for dryland pasture production: is it sustainable?

Eyob H. Tesfamariam*, John G. Annandale, Martin J. Steyn, Wayne F. Truter, Legesse K. Debusho, Deribe G. Talore

Department of Plant and Soil Science, University of Pretoria, Private Bag X20, 0002, Pretoria, South Africa.

* Corresponding author (eyob.tesfamariam@up.ac.za),+27 12420 4724; fax: +27

124204120 


\begin{abstract}
BACKGROUND: There are concerns that fertilization using sludge in semi-arid areas, where water is limiting, will compound the effect of drought, resulting in the decline of yield from potential salt accumulation. We investigated (8 years) impacts of annual sludge application at $0,4,8$, and $16 \mathrm{Mg} \mathrm{ha}^{-1}$ on weeping love grass hay yield, crude protein content $(\mathrm{CP})$, rainfall use efficiency (RUE) and nitrogen use efficiency (NUE), and trace metal uptake.

RESULTS: Both hay yield and RUE increased by $5-53 \%$ as the sludge rate increased. Hay yield was highest (13.3 $\left.\mathrm{Mg} \mathrm{ha}^{-1}\right)$ during the wet season while RUE $\left(27.1 \mathrm{~kg} \mathrm{~mm}^{-1}\right)$ during the dry season. Rainfall use efficiency was highest at sludge rates of $16 \mathrm{Mg} \mathrm{ha}^{-1}$ and NUE at $4 \mathrm{Mg} \mathrm{ha}^{-1}$. Similarly, municipal sludge application increased $\mathrm{CP}$ as well as crop $\mathrm{Cr}$ and $\mathrm{Zn}$ uptake from the $16 \mathrm{Mg} \mathrm{ha}^{-1}$ treatment.

CONCLUSION: Results from this study indicated that eight consecutive years of treated municipal sludge application increased weeping lovegrass hay yield, CP content and WUE. Similarly, trace metal uptake by crop did not differ between the zero control and the $16 \mathrm{Mg} \mathrm{ha}^{-1}$ treatment, except for $\mathrm{Zn}$ and $\mathrm{Cr}$, which showed a slight increment. Nonetheless all trace metals remained well below the domestic animals maximum tolerable dietary concentrations.
\end{abstract}

Key words: Trace metals; weeping lovegrass; Hay yield; Crude protein; Municipal sludge

Abbreviations: CP, crude protein; NUE, nitrogen use efficiency; RUE, rain use efficiency. 


\section{INTRODUCTION}

Pastures are ideal for sludge application because they are often situated in the close vicinity of urban areas; they display efficient nitrogen utilization under intensive management practices, and can be harvested repeatedly during the year. ${ }^{1}$

The use of municipal sludge with low contaminant concentrations on agricultural lands has been successfully deployed in many countries. ${ }^{2,3,4}$ The organic matter added through sludge improves soil structure thereby improving soil porosity, stability of aggregates, water retention, and cation exchange capacity (CEC) ${ }^{5,6,7} \mathrm{In}$ addition to improving soil structure, sludge is a good source of macro ${ }^{8}$ and micro nutrients. Recycling sewage sludge to pasture-based animal production is quite productive as nutrient sources. ${ }^{9}$

The use of sludge for pasture production is well-documented in the Northern

Hemisphere, especially U.S. ${ }^{1,10}$ and some European countries. ${ }^{8,11}$ However, little has been documented on forage yield, crude protein content, nitrogen and water use efficiency in Sub-Saharan African countries and other arid and semi-arid areas of the world, where both water and nitrogen, are limiting for pasture production. There are concerns that fertilization using sludge will compound the effect of drought, resulting in the decline of yield ${ }^{12}$ as a result of the potential salt accumulation. ${ }^{13}$ This is because both water deficit and osmotic effects are probably the major physiological mechanisms for growth reduction as both stresses lower the soil water potential. ${ }^{14}$

The aim of this study was to test the hypothesis that in semi-arid areas, where rainfall is erratic, continuous application of municipal sludge based on plant $\mathrm{N}$ 
requirements will not negatively affect weeping lovegrass hay yield, crude protein content, rainfall use efficiency, and nitrogen use efficiency regardless of the erratic rainfall nature of the area. Similarly, weeping lovegrass planted to soils amended with low trace metal concentration municipal sludge will not result in the accumulation of trace metals in the short to mid-term.

\section{MATERIALS AND METHODS}

\section{Field Site Description}

Field experiments were conducted at the East Rand Wastewater Care Works (ERWAT), Johannesburg, Gauteng, South Africa. The study site is situated at $26^{\circ}$ $01^{\prime} \mathrm{S}, 28^{\circ} 16^{\prime} \mathrm{E}, 1577 \mathrm{~m}$ asl. The annual rainfall ranged between $405 \mathrm{~mm}$ during the dry year of 2006/07 and $710 \mathrm{~mm}$ during the wet growing season of 2007/08, mainly during the months of October to March (Table 1). The soil is a clay loam (Hutton; Soil Classification Working Group, 1991) or a loamy, kaolinitic, mesic, Typic Eutrustox with an average soil profile depth $>1 \mathrm{~m}$ (Table 2). 
Table 1 Two-weekly mean temperature (Temp $\left(\mathrm{C}^{\circ}\right)$ ) and cumulative precipitation (mm) for the 2004/2005 to 2011/2012 growing seasons, ERWAT, Ekurhuleni district Pretoria, South Africa

\begin{tabular}{|c|c|c|c|c|c|c|c|c|c|c|c|c|c|c|c|c|c|c|c|c|c|c|c|}
\hline \multirow[b]{2}{*}{ Period } & \multirow{2}{*}{$\begin{array}{l}\text { Month } \\
\text { Weeks }\end{array}$} & \multicolumn{2}{|c|}{ Jan } & \multicolumn{2}{|c|}{ Feb } & \multicolumn{2}{|c|}{ Mar } & \multicolumn{2}{|c|}{ May } & \multicolumn{2}{|c|}{ Jun } & \multicolumn{2}{|c|}{ Jul } & \multicolumn{2}{|c|}{ Aug } & \multicolumn{2}{|c|}{ Sep } & \multicolumn{2}{|c|}{ Oct } & \multicolumn{2}{|c|}{ Nov } & \multicolumn{2}{|c|}{ Dec } \\
\hline & & $1-2$ & $3-4$ & $1-2$ & $3-4$ & $1-2$ & $3-4$ & $1-2$ & $3-4$ & $1-2$ & $3-4$ & $1-2$ & $3-4$ & $1-2$ & $3-4$ & $1-2$ & $3-4$ & $1-2$ & $3-4$ & $1-2$ & $3-4$ & $1-2$ & $3-4$ \\
\hline \multirow{2}{*}{2004} & $\begin{array}{l}\text { Temp } \\
\left(\mathrm{C}^{\mathrm{o}}\right)\end{array}$ & & & & & & & & & & & & & & & & & & & 22 & 23 & 22 & 22 \\
\hline & Rain (mm) & & & & & & & & & & & & & & & & & & & 12 & 29 & 72 & 64 \\
\hline \multirow{2}{*}{2005} & $\begin{array}{l}\text { Temp } \\
\left(\mathrm{C}^{\circ}\right)\end{array}$ & 23 & 21 & 22 & 21 & 20 & 15 & 14 & 13 & 12 & 11 & 10 & 12 & 13 & 15 & 17 & 19 & 19 & 20 & 20 & 21 & 20 & 20 \\
\hline & Rain(mm) & 111 & 56 & 17 & 79 & 27 & 18 & 1 & 0 & 0 & 0 & 0 & 0 & 0 & 0 & 0 & 0 & 0 & 12 & 55 & 54 & 35 & 68 \\
\hline \multirow{2}{*}{2006} & $\begin{array}{l}\text { Temp } \\
\left(\mathrm{C}^{\mathrm{o}}\right)\end{array}$ & 21 & 21 & 20 & 21 & 18 & 14 & 13 & 10 & 12 & 9 & 11 & 13 & 11 & 14 & 15 & 16 & 20 & 22 & 21 & 20 & 22 & 23 \\
\hline & Rain mm) & 51 & 57 & 103 & 70 & 13 & 9 & 0 & 3 & 0 & 0 & 0 & 0 & 10 & 30 & 0 & 0 & 0 & 13 & 42 & 75 & 13 & 121 \\
\hline \multirow[t]{2}{*}{2007} & $\begin{array}{l}\text { Temp } \\
\left(\mathrm{C}^{\mathrm{o}}\right)\end{array}$ & 21 & 21 & 21 & 23 & 22 & 15 & 13 & 10 & 10 & 9 & 8 & 11 & 11 & 13 & 20 & 18 & 16 & 16 & 19 & 20 & 18 & 19 \\
\hline & Rain (mm) & 47 & 24 & 30 & 0 & 6 & 19 & 0 & 0 & 29 & 0 & 0 & 0 & 0 & 0 & 0 & 17 & 85 & 34 & 4 & 45 & 68 & 12 \\
\hline \multirow[t]{2}{*}{2008} & $\begin{array}{l}\text { Temp } \\
\left(\mathrm{C}^{\circ}\right)\end{array}$ & 20 & 18 & 19 & 21 & 19 & 17 & 16 & 13 & 12 & 12 & 10 & 12 & 14 & 15 & 17 & 16 & 19 & 20 & 20 & 20 & 21 & 21 \\
\hline & Rain (mm) & 59 & 148 & 56 & 5 & 117 & 0 & 33 & 10 & 14 & 3 & 0 & 0 & 0 & 0 & 0 & 0 & 0 & 52 & 52 & 45 & 59 & 67 \\
\hline \multirow[t]{2}{*}{2009} & $\begin{array}{l}\text { Temp } \\
\left(\mathrm{C}^{\mathrm{o}}\right)\end{array}$ & 22 & 21 & 23 & 21 & 20 & 19 & 17 & 15 & 14 & 13 & 13 & 11 & 10 & 13 & 14 & 14 & 19 & 20 & 25 & 20 & 23 & 23 \\
\hline & Rain (mm) & 111 & 57 & 21 & 73 & 15 & 56 & 45 & 18 & 1 & 0 & 0 & 0 & 0 & 0 & 1 & 0 & 14 & 1 & 4 & 90 & 12 & 27 \\
\hline \multirow[t]{2}{*}{2010} & $\begin{array}{l}\text { Temp } \\
\left(\mathrm{C}^{\circ}\right)\end{array}$ & 23 & 21 & 23 & 21 & 19 & 19 & 17 & 15 & 14 & 13 & 12 & 11 & 10 & 13 & 14 & 14 & 18 & 21 & 24 & 20 & 23 & 23 \\
\hline & Rain (mm) & 111 & 57 & 21 & 73 & 15 & 56 & 52 & 11 & 1 & 0 & 0.1 & 0 & 0 & 0 & 1 & 0 & 14 & 1 & 4 & 90 & 12 & 27 \\
\hline \multirow[t]{2}{*}{2011} & $\begin{array}{l}\text { Temp } \\
\left(\mathrm{C}^{\circ}\right)\end{array}$ & 19 & 21 & 20 & 19 & 21 & 20 & 17 & 14 & 15 & 13 & 11 & 10 & 8 & 10 & 12 & 14 & 18 & 16 & 17 & 21 & 20 & 19 \\
\hline & Rain (mm) & 94 & 76 & 29 & 35 & 84 & 51 & 38 & 31 & 5 & 1 & 22 & 0 & 0 & 0 & 5 & 0 & 2 & 0 & 37 & 45 & 5 & 75 \\
\hline \multirow[t]{2}{*}{2012} & $\begin{array}{l}\text { Temp } \\
\left(\mathrm{C}^{\circ}\right)\end{array}$ & 20.7 & 19.8 & 20.4 & 21.1 & 19.7 & 18.5 & 14.9 & 16.0 & 17.4 & 12.8 & 10.2 & 10.9 & 11.7 & 11.6 & 10.1 & 17.7 & 13.4 & 16.1 & 19.1 & 17.0 & 18.3 & 20.0 \\
\hline & $\mathrm{R}$ & 74 & 52 & 23 & 69 & 22 & 29 & 2 & 13 & 0 & 0 & 0 & 3 & 0 & 0 & 0 & 0 & 88 & 7 & 27 & 40 & 10 & 60 \\
\hline
\end{tabular}




\section{Sludge Characteristics}

The sludge used in this study is mainly of domestic origin (96\%) with the rest $4 \%$ accounting from industry. The sludge was digested anaerobically to $44 \%$ volatile suspended solid destruction in mesophilic anaerobic digesters with a retention time of 17 days (15 primary and 2 secondary). The sludge was dried on concrete beds in thick layers of $25 \mathrm{~cm}$ before applying to the experimental plots. According to the current South African sludge guideline,${ }^{15}$ as described by Tesfamariam ${ }^{16}$, this sludge is classified as pollutant class "a" because of its low trace metal content (Table 3). The only exception was the high $\mathrm{Zn}$ concentration reported in 2008/09, 2009/10 and 2010/11 causing the sludge to be categorized as class "b". On the basis of the microbiological report from the ERWAT laboratory, the sludge didn't have viable pathogens and is classified as microbiological class "A". Considering the low odour and vector attraction characteristics of the sludge, it is classified as stability class 1 . This sludge type (A1a) is equivalent to the EPA class D biosolid. The current South African sludge guideline allows such quality sludge to be utilized in agriculture without restriction, as long as the $\mathrm{N}$ applied does not exceed crop demand, with the upper limit set at $8 \mathrm{Mg} \mathrm{ha}^{-1}$ per year. Selected chemical characteristics of this A1a sludge are presented in Table 3.

\section{Field Trial and Treatments}

The study was conducted in a formerly natural grassland area. Plots of $25 \mathrm{~m}^{2}$ were arranged in a randomized complete block design comprising four replications of four treatments. The

treatments consisted of 0 (control), 4,8 , and $16 \mathrm{Mg} \mathrm{ha}^{-1}$ dry sludge per hectare per year. The $8 \mathrm{Mg} \mathrm{ha}^{-1} \mathrm{yr}^{-1}$ treatment represents the former South African upper sludge application rate, which was still in place, when this study commenced. The $4 \mathrm{Mg} \mathrm{ha}^{-1}$ and $16 \mathrm{Mg} \mathrm{ha}^{-1}$ 
treatments represent half and double of this former norm. The annual sludge application rate was split into two so that half was applied at the beginning of the season and the remaining half following the first cut.

At the beginning of the study, during the 2004/05 growing season, the sludge was broadcasted over the soil surface and immediately incorporated into the top 0.1-m soil layer with a manually operated, diesel powered rotovator (Agria). After sludge incorporation, the soil was leveled using rakes. A mixture of perennial weeping lovegrass $\left(10 \mathrm{~kg} \mathrm{ha}^{-1}\right)$ and teff (Eragrostis teff) $\left(6 \mathrm{~kg} \mathrm{ha}^{-1}\right)$ were planted on 15 Nov. 2004 and a hand drawn roller was used to ensure good seed-soil contact for better germination. In this experiment, teff was mainly planted as a nurse crop to suppress weed growth. It is an annual grass and after the first harvest in 2004/05 growing season, the plots were fully covered by weeping lovegrass. During the rest of the study period, however, the sludge was broadcast over the soil surface of the already established weeping lovegrass plots.

\section{Sampling and Analyses}

Above-ground samples for hay dry matter yield determination were collected $0.05 \mathrm{~m}$ above the soil surface at about $50 \%$ flowering from a $1 \mathrm{~m}^{2}$ area. Generally, two rounds of sampling for hay dry matter yield determination took place per annum and the hay dry matter yield presented reflects the cumulative yield per year. The samples were dried in a forced oven at $60^{\circ} \mathrm{C}$ until plant material reached constant weight. In addition, a hand grab of grass samples were collected at harvest from each plot for grass $\mathrm{N}$ content determination. Crude protein content was estimated by multiplying hay $\mathrm{N}$ content by a factor of 6.25 . Nitrogen use efficiency (NUE) $\left(\mathrm{kg} \mathrm{DM} \mathrm{kg}^{-1} \mathrm{~N}\right)$ was estimated using Eq. ${ }^{17}$ and rainfall use efficiency (RUE) using Eq. $2^{18}$. 
Table 2 Selected physical and chemical characteristics of the soil at the study (ERWAT, Ekurhuleni district Pretoria, South Africa)

\begin{tabular}{|c|c|c|c|c|c|c|c|c|}
\hline \multirow{2}{*}{$\begin{array}{l}\text { Soil layer depth } \\
\text { (m) }\end{array}$} & Sand & Silt & Clay & TOC & TON & \multirow[b]{2}{*}{$\mathrm{C} / \mathrm{N}$} & \multirow{2}{*}{$\begin{array}{c}\mathrm{EC} \\
\mathrm{mS} \mathrm{m} \mathrm{m}^{-1}\end{array}$} & \multirow{2}{*}{$\begin{array}{c}\mathrm{pH} \\
\left(\mathrm{H}_{2} \mathrm{O}\right.\end{array}$} \\
\hline & \multicolumn{5}{|c|}{$\mathrm{g} \mathrm{kg}^{-1}$} & & & \\
\hline $0-0.3$ & 364 & 256 & 380 & 16.77 & 1.41 & 11.86 & 30.67 & 5.73 \\
\hline $0.3-0.7$ & 362 & 225 & 413 & 8.74 & 0.89 & 9.79 & 21.00 & 5.58 \\
\hline $0.7-1.2$ & 368 & 205 & 427 & 3.70 & 0.54 & 6.82 & 10.67 & 5.59 \\
\hline
\end{tabular}

$\mathrm{NUE}=($ Sludge treated plot yield $(\mathrm{kg})-$ Zero sludge plot yield $(\mathrm{kg})) /(\mathrm{N}$ applied $(\mathrm{kg}))$

$$
\text { RUE }=\text { Hay dry biomass yield }\left(\mathrm{kg} \mathrm{m}^{-2}\right) / \text { Rainfall }(\mathrm{mm})
$$

Total $\mathrm{P}$ in sludge as well as trace metals in plant samples and sludge were determined after wet acid digestion using an Inductively Coupled Plasma Optical Emission Spectrometer (ICP-OES) (SpectroFlame Modula; Spectro, Kleve, Germany). The wet acid digestion was conducted on a ground $0.5 \mathrm{~g}$ sample, which was digested with $7 \mathrm{ml} \mathrm{HNO}_{3}$ (conc. nitric acid, $65 \%$ ) and $3 \mathrm{ml} \mathrm{HClO}_{4}$ (perchloric acid, 70\%) at temperatures up to $180^{\circ} \mathrm{C}$. This was followed by the gradual addition of $0.5 \mathrm{ml} \mathrm{H}_{2} \mathrm{O}_{2}$ (hydrogen peroxide, 50\%) further heating for 20 minutes. The digestate was removed from the block to partially cool down for about 10 minutes. Finally a $10 \mathrm{ml}$ of a 1:1 hydrochloric acid solution was added and shaken to mix before transferring to a $100 \mathrm{ml}$ volumetric flask. Sludge and plant samples were ground to pass through a $150 \mu \mathrm{m}$ screen and analyzed for total $\mathrm{C}$ and $\mathrm{N}$ using a Carlo Erba NA1500 C/N analyzer (Carlo ErbaStrumentazione, Milan, Italy). Sludge samples were extracted in 1:5 $1 \mathrm{M} \mathrm{KCl}$ and tested for ammonium and nitrate with the Lachat Autoanalyzer (Lachat Quick Chem Systems, Milwaukee, WI, U.S.). Sludge electrical conductivity was analyzed on 1:2 sludge to water ratio extract. Extracts were analyzed for electrical conductivity using a Beckman conductivity bridge and reported in units of $\mathrm{mS} / \mathrm{m}$. 
Table 3 Chemical characteristics of anaerobically digested, paddy dried sludge used during the 2004/05 - 2011/12 growing seasons

Year

\begin{tabular}{|c|c|c|c|c|c|c|c|c|c|}
\hline Element & Unit & $2004 / 05$ & 2005/06 & 2006/07 & $2007 / 08$ & 2008/09 & $2009 / 10$ & 2010/11 & $2011 / 12$ \\
\hline $\mathrm{N}$ & $\mathrm{g} \mathrm{kg}^{-1}$ & 30.3 & 18.8 & 22.2 & 30.9 & 27.4 & 22.4 & 27.5 & 21.6 \\
\hline $\mathrm{NH}_{4} \_\mathrm{N}$ & $\mathrm{mg} \mathrm{kg}^{-1}$ & 2018 & 4362 & 4064 & 7660 & 3000 & 3542 & 3260 & 2106 \\
\hline $\mathrm{NO}_{3} \_\mathrm{N}$ & $\mathrm{mg} \mathrm{kg}^{-1}$ & 183 & 6 & 40 & 11 & 180 & 95 & 138 & 50 \\
\hline $\mathrm{P}$ & $\mathrm{g} \mathrm{kg}^{-1}$ & 19.6 & 18.4 & 27.6 & 22.4 & 34.3 & 31.3 & 42.04 & 30.2 \\
\hline P- Bray1 & $\mathrm{mg} \mathrm{kg}^{-1}$ & 166 & 154 & 40 & 66 & 50 & 80 & 120 & 187 \\
\hline Total C & $\mathrm{g} \mathrm{kg}^{-1}$ & 230 & 200 & 210 & 200 & 212 & 166 & 219.6 & 180 \\
\hline $\begin{array}{l}\text { Water } \\
\text { content }\end{array}$ & $\mathrm{g} \mathrm{kg}^{-1}$ & 460 & 300 & 280 & 380 & 340 & 404 & 655 & 440 \\
\hline $\mathrm{EC}_{\mathrm{e}}$ & $\mathrm{mS} \mathrm{m}^{-1}$ & 1814 & 1212 & 1412 & 3110 & 945 & 1559 & 1218 & 1423 \\
\hline K & $\mathrm{mg} \mathrm{kg}^{-1}$ & 3804 & 710 & 689 & 1356 & 1720 & 2530 & 1850 & 2710 \\
\hline $\mathrm{Ca}$ & $\mathrm{mg} \mathrm{kg}^{-1}$ & 25116 & 13062 & 17450 & 10042 & 26950 & 23147 & 28312 & 28600 \\
\hline $\mathrm{Mg}$ & $\mathrm{mg} \mathrm{kg}^{-1}$ & 5358 & 591 & 829 & 1145 & 3410 & 3490 & 3624 & 3860 \\
\hline $\mathrm{pH}$ & $\left(\mathrm{H}_{2} \mathrm{O}\right)$ & 6.01 & 6.2 & 6.02 & 6.08 & 8.1 & 5.7 & 5.6 & 4.7 \\
\hline $\mathrm{Cd}$ & $\mathrm{mg} \mathrm{kg}^{-1}$ & 1.63 & 0.07 & 0.15 & 18.91 & 19.0 & 12.2 & 10.75 & 3 \\
\hline $\mathrm{Hg}$ & $\mathrm{mg} \mathrm{kg}^{-1}$ & 1.70 & 0.02 & 0.03 & 1.81 & 1 & 1 & 0.4 & 0.4 \\
\hline $\mathrm{Cr}$ & $\mathrm{mg} \mathrm{kg}^{-1}$ & 51.93 & 1.50 & 2.92 & 503.8 & 419 & 369.7 & 315.8 & 249 \\
\hline As & $\mathrm{mg} \mathrm{kg}^{-1}$ & 7.08 & 0.18 & 0.23 & 17.94 & 6.5 & 5.88 & 5.64 & 5.9 \\
\hline $\mathrm{Pb}$ & $\mathrm{mg} \mathrm{kg}^{-1}$ & 54.46 & 9.41 & 1.37 & 102.0 & 75 & 88.38 & 66.76 & 46 \\
\hline $\mathrm{Zn}$ & $\mathrm{mg} \mathrm{kg}^{-1}$ & 459.9 & 4.33 & 20.85 & 2325 & 4920 & 3459 & 5755 & 2886 \\
\hline $\mathrm{Ni}$ & $\mathrm{mg} \mathrm{kg}^{-1}$ & 23.81 & 1.37 & 0.97 & 144.5 & 152 & 111.13 & 103.27 & 127 \\
\hline $\mathrm{Cu}$ & $\mathrm{mg} \mathrm{kg}^{-1}$ & 97.2 & 3.21 & 4.59 & 526.8 & 681 & 497.29 & 544.52 & 440 \\
\hline
\end{tabular}




\section{Statistical Analyses}

Statistical analyses were performed to evaluate the effect of various sludge application rates on hay yield, crude protein contents, rainfall use efficiency, and Nitrogen use efficiency. These variables (termed as response variables) were measured from the same blocks every year for eight consecutive years and this constituted a repeated measures data. Because the year or time is a quantitative variable we model the response variables as a polynomial function of time. Furthermore, the plots for the combined annual means of the response variables (see Figures 2 and 3) indicate that higher order polynomial terms of time should be added in the model. Therefore, quadratic equations for regressions of these responses on time were introduced to the fitted models. The data were analyzed using Procedure MIXED of SAS. ${ }^{19}$ This procedure provides specification of various types of covariance structures for repeated measurements. The covariance and correlation matrices obtained from the data sets (for brevity results not shown) suggested analyzing the data using heterogeneous variances with time. Since there were sufficient observations for hay yield, crude protein content and rainfall use efficiency, the unstructured (UN) covariance matrix model was used first but the number of observations for nitrogen use efficiency were relatively small to consider this model. Since the measurements were done at equal time intervals the heterogeneous autoregressive of order one (ARH(1)) was used. 
When treatment effects were found to be significant, LSMEANS option was used to compare the mean value of the response variable between the different treatments at 0.05 level.

\section{RESULTS}

\section{Hay Yield}

There was a highly significant $(P<0001)$ year $\times$ sludge application treatment interaction for weeping lovegrass hay yield when data were combined for all years (Table 4). The dry matter yield showed great variations in response to rainfall variability as indicated in Fig. 1a.

Table 4 Type 3 tests of fixed effects for weeping love grass hay yield, crude protein content, rainfall use efficiency, and nitrogen use efficiency as affected by sludge application rate, time and quadratic time effects

\begin{tabular}{|c|c|c|c|c|c|c|c|c|}
\hline Parameter & Hay & ield & Crude & rotein & $\begin{array}{r}\text { Rain } \\
\text { effi }\end{array}$ & $\begin{array}{l}\text { use } \\
\text { acy }\end{array}$ & $\begin{array}{l}\text { Nitrog } \\
\text { effic }\end{array}$ & $\begin{array}{l}n \text { use } \\
\text { ncy }\end{array}$ \\
\hline Effect & $\begin{array}{c}\mathbf{F} \\
\text { Value }\end{array}$ & $\operatorname{Pr}>F$ & $\begin{array}{c}\mathbf{F} \\
\text { Value }\end{array}$ & $\operatorname{Pr}>F$ & $\begin{array}{c}\mathbf{F} \\
\text { Value }\end{array}$ & $\operatorname{Pr}>\mathbf{F}$ & $\begin{array}{c}\mathbf{F} \\
\text { Value }\end{array}$ & $\operatorname{Pr}>\mathbf{F}$ \\
\hline Treatment & 105.58 & $<.0001$ & 1158.24 & $<.0001$ & 86.81 & $<.0001$ & 1608.23 & $\begin{array}{c}< \\
0.0001\end{array}$ \\
\hline Time & 458.71 & $<.0001$ & 528.59 & $<.0001$ & 35.23 & $<.0001$ & 3017.56 & $\begin{array}{c}< \\
0.0001\end{array}$ \\
\hline Time*Treatment & 24.10 & $<.0001$ & 243.41 & $<.0001$ & 61.72 & $<.0001$ & 1623.12 & $\begin{array}{c}< \\
0.0001\end{array}$ \\
\hline Time2 & 377.72 & $<.0001$ & 585.66 & $<.0001$ & 0.17 & 0.7043 & 3792.57 & $\begin{array}{c}< \\
0.0001\end{array}$ \\
\hline Time $2 *$ Treatment & 29.13 & $<.0001$ & 545.07 & $<.0001$ & 45.99 & $<.0001$ & 1885.47 & $\begin{array}{c}< \\
0.0001\end{array}$ \\
\hline Block & 1.62 & 0.2522 & 1262.98 & $<0.0001$ & 2.73 & 0.1057 & 1058.58 & $\begin{array}{c}< \\
0.0001\end{array}$ \\
\hline
\end{tabular}




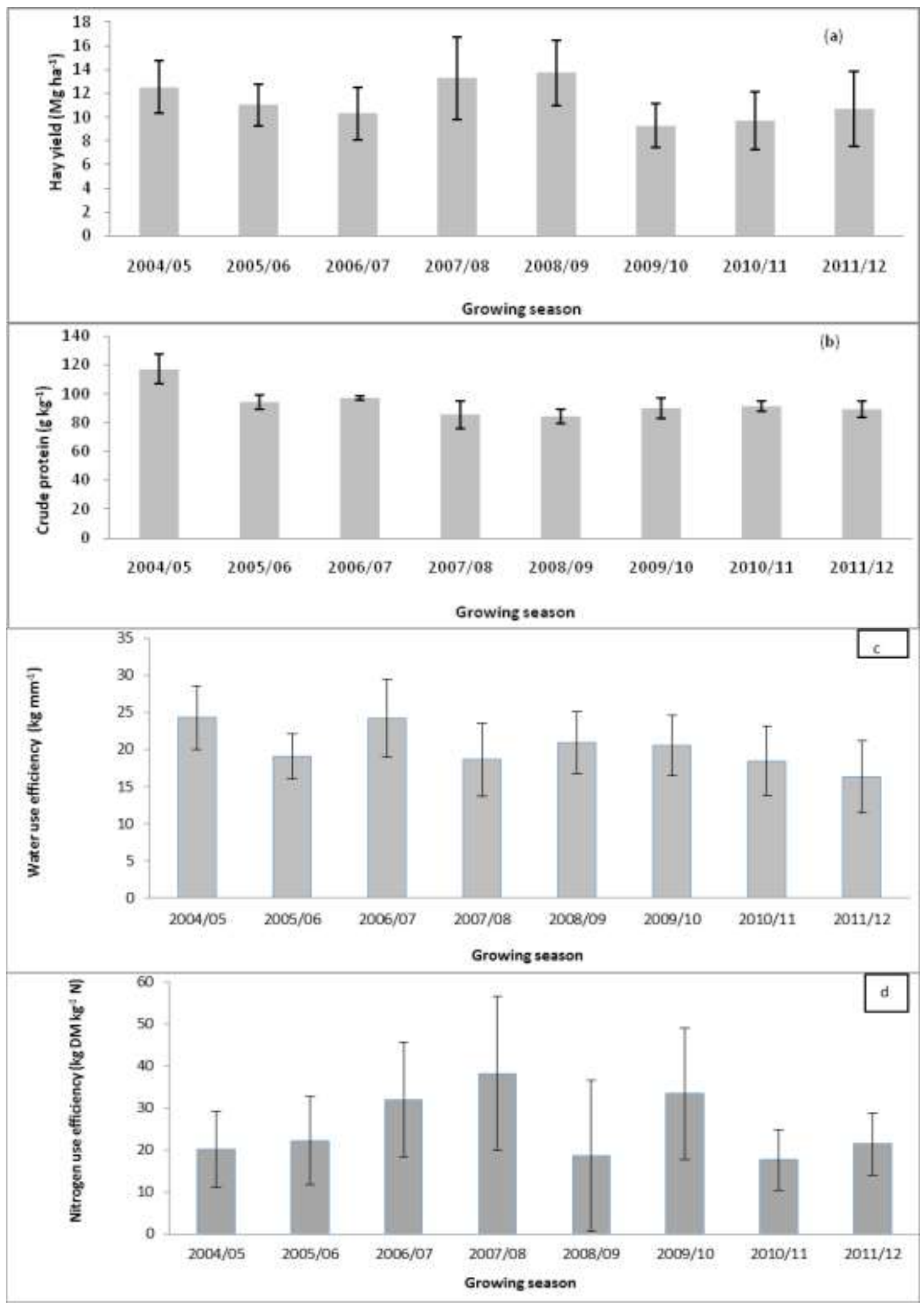

Figure 1 Mean hay yield (a), crude protein content (b), Rainfall Use Efficiency (RUE) (c), Nitrogen Use Efficiency (NUE) of weeping lovegrass combined for all treatments during the $2004 / 05$ to $2011 / 12$ growing seasons 
The hay dry matter yield increased as the sludge application rate increased for all years (Fig. 2).

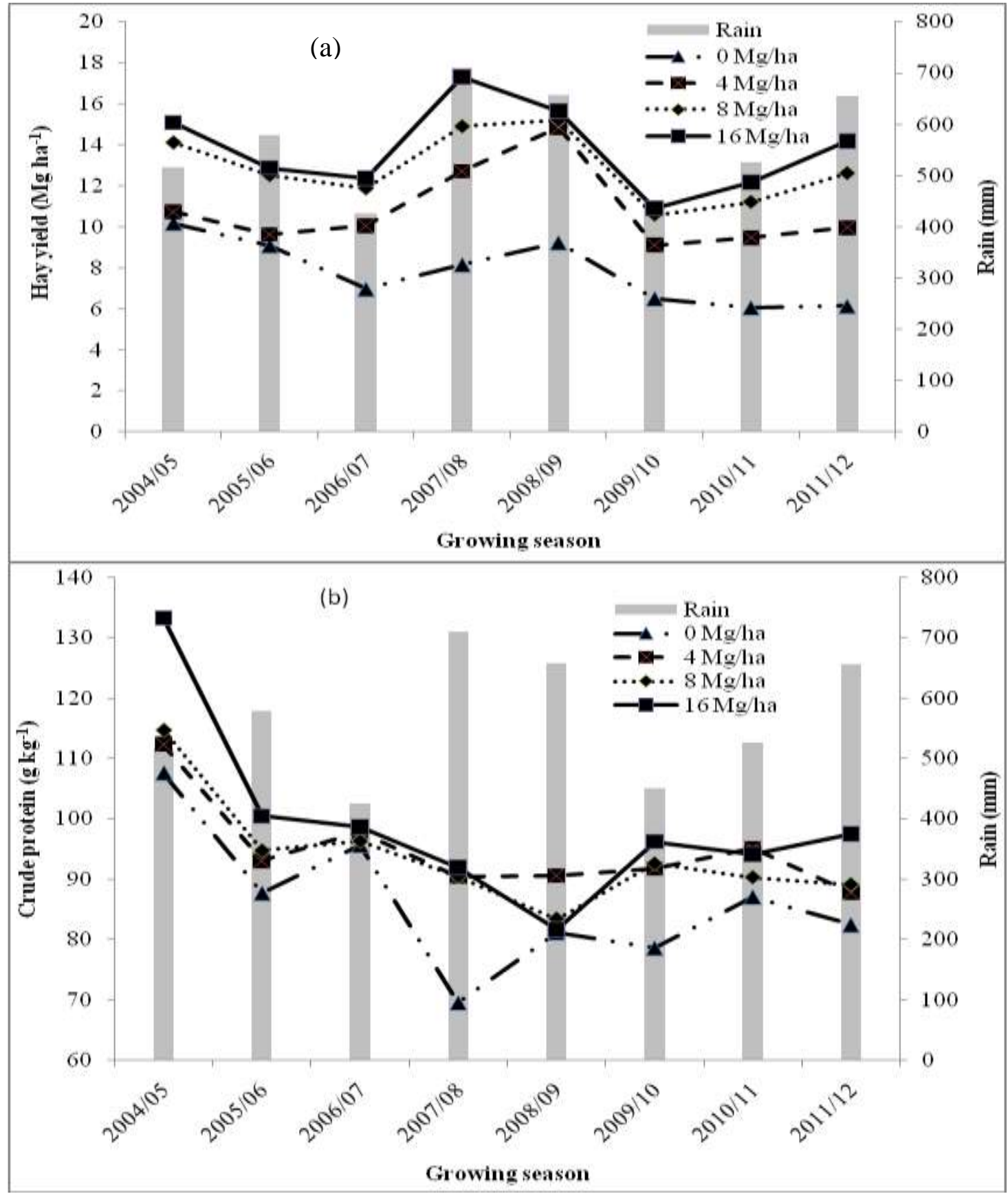

Figure 2 Combined annual mean hay yield (a) and crude protein content (b) of weeping lovegrass as affected by different rates of sludge application and amount of of rain(mm) during the 2004/05 to 2011/12 growing seasons 
The pattern of yield response to sludge application rate remained similar regardless of the rainfall variation. The highest hay yield $\left(17.31 \mathrm{Mg} \mathrm{ha}^{-1}\right)$ was harvested during the relatively wet season of $2007 / 08$ (707 mm rain) from the $16 \mathrm{Mg} \mathrm{ha}^{-1}$. In contrast, hay yield was generally low during the dry 2006/07 and 2009/10 growing periods (426 mm rain) for all treatments (Fig 2).

\section{Crude Protein Content}

There was a statistically highly significant $(\mathrm{p}<0.0001)$ year $\mathrm{x}$ sludge treatment interaction (Table 4). Generally the application of sludge improved $(P<0001)$ the crude protein content relative to the zero control, in six of the 8 growing seasons (Fig. 2b). Highest CP content was recorded for the 2004/05 growing season (Fig 1b), where Eragrostis teff was planted as a nurse crop. Crude protein showed a generally decreasing pattern after the 2006/07 growing season. Overall doubling of the annual upper sludge limit improved weeping lovegrass crude protein content but was statistically significant only in four $(2004 / 05,2005 / 06,2010 / 11,2011 / 12)$ of the eight growing seasons (Fig. 2b). The overall CP contents ranged between 70-135 g $\mathrm{kg}^{-1}$ on dry matter basis.

\section{Rainfall and Nitrogen Use Efficiency}

There was a significant $(P<0.0001)$ year $\mathrm{x}$ sludge application treatment interaction for weeping lovegrass RUE and NUE when data were combined for all years (Table 4). Generally RUE was improved with the application of sludge and it increased as the sludge application rate increased (Fig. 3a). Rainfall use efficiency indicated a declining pattern as the years progressed. 


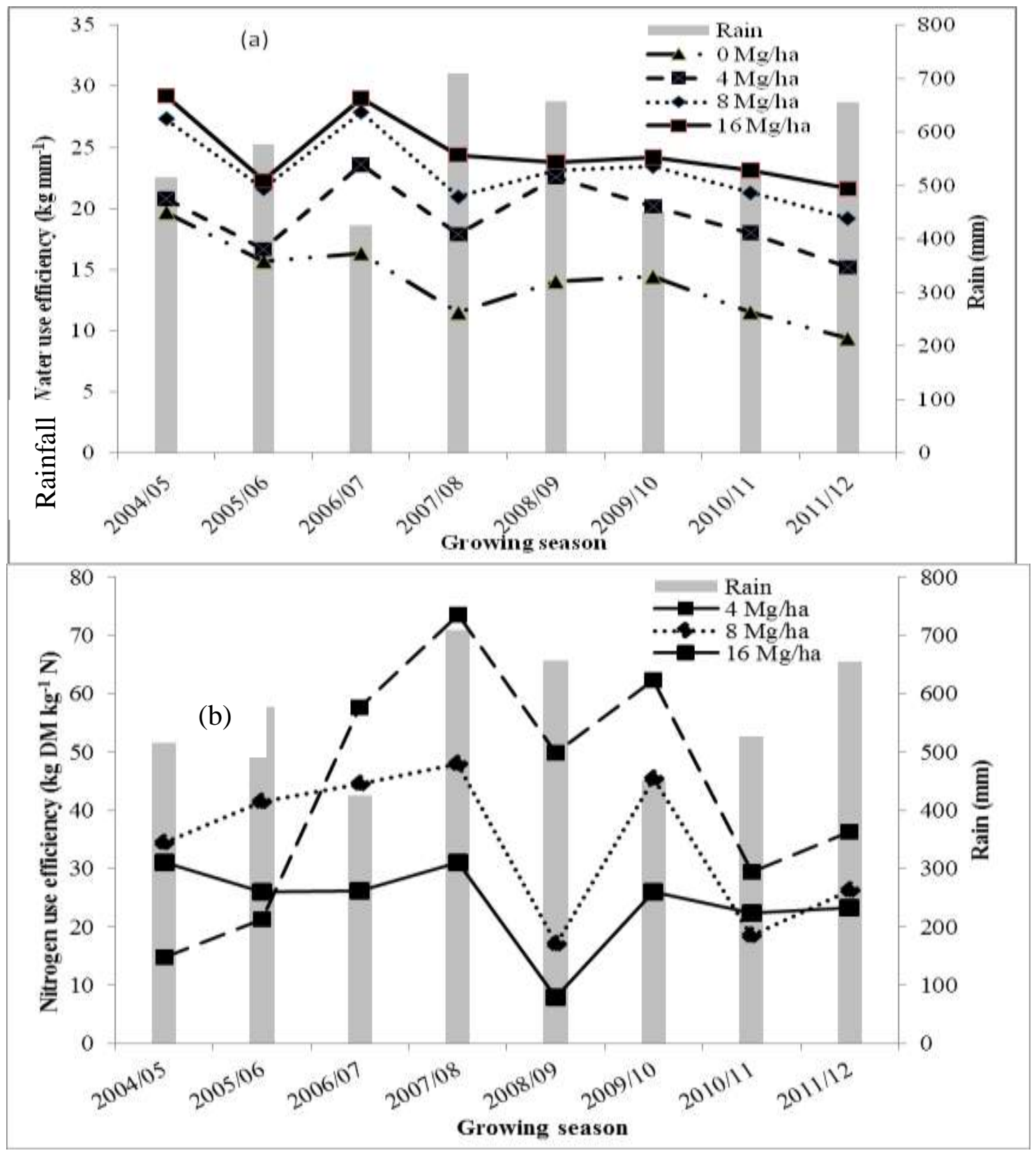

Figure 3 Weeping lovegrass mean Rain (RUE) (a) and nitrogen use efficiency (NUE) (b) as affected by sludge application rate during the 2004/05 to 2011/12 growing seasons

Nitrogen use efficiency of weeping lovegrass increased significantly $(P<$ 0.0001) across years during the first four years for both the 4 and $8 \mathrm{Mg} \mathrm{ha}^{-1}$ sludge 
treatments (Fig. 3b). After the fourth year, all treatments showed a harmonic decline for the last four years with the $4 \mathrm{Mg} \mathrm{ha}^{-1}$ treatment showing the highest reduction $\left(37.28 \mathrm{~kg} \mathrm{DM} \mathrm{kg}^{-1} \mathrm{~N}\right)$ and the $16 \mathrm{Mg} \mathrm{ha}^{-1}$ treatment the least $\left(7.83 \mathrm{~kg} \mathrm{DM} \mathrm{kg}^{-1} \mathrm{~N}\right)$.

\section{Trace Metal Uptake}

The mean ( \pm s.e.m) concentration of $\mathrm{Ar}, \mathrm{Cd}, \mathrm{Cr}, \mathrm{Co}, \mathrm{Mo}, \mathrm{Ni}, \mathrm{Pb}, \mathrm{V}, \mathrm{Se}$, and $\mathrm{Zn}$ in weeping lovegrass is presented in Table 5. Continuous sludge application at rates of $16 \mathrm{Mg} \mathrm{ha}^{-1}$ significantly increased $(\mathrm{P}<0.05) \mathrm{Cr}$ and $\mathrm{Zn}$ uptake by weeping lovegrass compared with the zero control both in 2007/08 and 2010/11 growing seasons. Although there was an increase in crop uptake of $\mathrm{Ni}, \mathrm{V}$, and $\mathrm{Se}$ with the application of sludge, the difference was not statistically significant. Elements such as As and Cd, however, did not show consistent pattern across years. Nonetheless, the concentrations of all elements remained far lower than the maximum tolerable dietary concentrations for domestic animals (Table 5). 
Table 5 Mean trace metal uptake by weeping lovegrass planted to a clay loam soil that received 0 and $16 \mathrm{Mg} \mathrm{ha}^{-1} \mathrm{yr}^{-1} \mathrm{municipal}$ sludge for eight years $(2004 / 05-2011 / 12)$

\begin{tabular}{|c|c|c|c|c|c|}
\hline \multirow[b]{3}{*}{ Element } & \multicolumn{4}{|c|}{ Grass trace metal uptake } & \multirow{3}{*}{$\begin{array}{l}\text { Domestic animals maximum tolerable dietary } \\
\text { concentration (NRC, 2005) }\end{array}$} \\
\hline & \multicolumn{2}{|c|}{$2007 / 08$} & \multicolumn{2}{|c|}{$2011 / 12$} & \\
\hline & $\underset{\mathrm{yr}^{-1}}{0 \mathrm{Mg} \mathrm{ha}^{-1}}$ & $\begin{array}{c}16 \mathrm{Mg} \mathrm{ha}^{-1} \\
\mathrm{yr}^{-1}\end{array}$ & $\begin{array}{c}0 \mathrm{Mg} \mathrm{ha}^{-1} \\
\mathrm{yr}^{-1}\end{array}$ & $\begin{array}{c}16 \mathrm{Mg} \mathrm{ha}^{-1} \\
\mathrm{yr}^{-1}\end{array}$ & \\
\hline As & $0.02 \pm 0.008$ & $0.03 \pm 0.008$ & $0.03 \pm 0.013$ & $0.03 \pm 0.021$ & 30 (horse, cattle, sheep, swine, and poultry) \\
\hline $\mathrm{Cd}$ & $0.183 \pm 0.004$ & $0.163 \pm 0.003$ & $0.085 \pm 0.019$ & $0.085 \pm 0.003$ & 10 (horse, cattle, sheep, swine, and poultry) \\
\hline $\mathrm{Cr}$ & $1.27 \pm 0.07$ & $1.49 \pm 0.01$ & $1.32 \pm 0.009$ & $1.44 \pm 0.015$ & $\begin{array}{c}3000 \text { (oxide) } 100 \text { (soluble chromium } \mathrm{Cr}^{+++} \text {) (horse, } \\
\text { cattle and sheep) }\end{array}$ \\
\hline Co & $0.272 \pm 0.004$ & $0.252 \pm 0.006$ & $0.228 \pm 0.010$ & $0.213 \pm 0.007$ & 25 (poultry, horse, cattle and sheep) \\
\hline Mo & $0.24 \pm 0.004$ & $0.19 \pm 0.01$ & $0.32 \pm 0.043$ & $0.28 \pm 0.011$ & 5 (horses, cattle and sheep) \\
\hline $\mathrm{Ni}$ & $3.7 \pm 0.19$ & $3.9 \pm 0.08$ & $1.981 \pm 0.019$ & $2.17 \pm 0.016$ & $\begin{array}{c}100 \text { (cattle and sheep); } 50 \text { (horses); } 250 \text { (poultry } \\
\text { and swine) }\end{array}$ \\
\hline $\mathrm{Pb}$ & $0.85 \pm 0.03$ & $0.96 \pm 0.07$ & $0.934 \pm 0.053$ & $0.784 \pm 0.005$ & 100 (cattle and sheep); 10 (poultry, swine and horses) \\
\hline V & $0.79 \pm 0.01$ & $0.85 \pm 0.07$ & $0.81 \pm 0.013$ & $0.82 \pm 0.01$ & 50 (cattle and sheep); 10 (swine and horses) \\
\hline $\mathrm{Se}$ & $0.44 \pm 0.02$ & $0.52 \pm 0.02$ & $0.45 \pm 0.091$ & $0.53 \pm 0.012$ & 5 (horses, cattle and sheep); 3 (poultry); 4 (swine) \\
\hline $\mathrm{Zn}$ & $27 \pm 4.18$ & $49 \pm 6.83$ & $25.3 \pm 3.872$ & $50.3 \pm 5.20$ & 500 (cattle and horse); 300 (sheep) \\
\hline
\end{tabular}




\section{DISCUSSIONS}

\section{Hay Yield}

The year $\times$ sludge application treatment interaction for hay yield was primarily caused by hay yield magnitude differences among the years. Within the same growing season, hay yield increased with doubling of sludge application rate both during dry (2006/07) and wet seasons (2007/08) mainly because of an increase in nutrient availability especially $\mathrm{N}$. This concurs with previous studies which reported an increase in weeping lovegrass dry matter production as the rate of nutrient application increased. ${ }^{9,20,21,22}$

The year $\mathrm{x}$ sludge interaction for the combined analyses across years is mainly attributed to the variation in the rainfall (Fig. 2a) as well as the sludge $\mathrm{N}$ content across years (Table 3). For instance, the N content of sludge in 2006/07 $(2.22 \%)$ was higher than 2005/06 (1.88\%). However, hay yield was higher in $2005 / 06$ than similar treatments in $2006 / 07$ because of the relatively higher rainfall received in 2005/06.

In general, hay yield throughout the study period was much higher than the local long term average values of $6 \mathrm{Mg} \mathrm{ha}^{-1}$ but was still within the local ranges. ${ }^{21}$ Similarly, hay yield from this study was within the ranges reported from U.S. ${ }^{23}$, despite the differences in soil and climate. The nutrient mass balance of the current study have shown that sludge applied at double the recommended rate $\left(16 \mathrm{Mg} \mathrm{ha}^{-1}\right)$ did not lead to the accumulation of nitrate and 
ammonium in the soil profile but led to the accumulation of total and Bray 1 extractable $\mathrm{P} .{ }^{16}$ Thus, there is a strong evidence to accept the alternative hypothesis stated that municipal sludge application based on crop $\mathrm{N}$ requirements had less general negative effect in the short term on weeping lovegrass hay yield planted to deep red clay loam soils that received rainfall of 405 to $710 \mathrm{~mm}$.

\section{Crude Protein Content}

Protein is the most important constituent and costly component of feed nutrients limiting animal performance feeding on pasture. ${ }^{24}$ Higher protein content $(80-160 \mathrm{~g}$ $\mathrm{kg}^{-1}$ ) in a given feed is usually desirable for maintenance, growth, production and normal feed intake and functioning of rumen microflora. Generally, the CP content for all the treatments from this study were within the ranges reported for weeping lovegrass $\left(63-175 \mathrm{~g} \mathrm{~kg}^{-1}\right){ }^{25,26}$ It was also above the minimum crude protein requirements of ruminants $\left(70-80 \mathrm{~g} \mathrm{~kg}^{-1}\right){ }^{24}$

The year $\times$ sludge application treatment interaction for crude protein means the interaction was primarily caused by crude protein magnitude differences among the years. Within the same growing season, $\mathrm{CP}$ increased with doubling of sludge application rate in four of eight growing seasons mainly because of an increase in nutrient availability especially $\mathrm{N}$. The year $\mathrm{x}$ sludge interaction for the combined analyses across years is mainly attributed to the variation in the rainfall (Fig. 2b), the variation in sludge $\mathrm{N}$ content across years (Table 3 ) as well as $\mathrm{N}$ carry over effects from previous seasons. 
The CP content of weeping lovegrass for all treatments from the first growing season (2004/05) was generally higher than similar treatments during the other seven years (Fig 2). This is mainly attributed to the higher crude content of Eragrostis teff, ${ }^{27}$ which was planted as a nurse crop, during the establishment year in $2004 / 05$.

The increase in the $\mathrm{CP}$ content with the application of sewage sludge was due, in large measure to the increase in the availability of $\mathrm{N}$. This is because $\mathrm{CP}$ content of weeping lovegrass increases with fertilization under nutrient limiting conditions. ${ }^{28,29,30}$

\section{Rainfall and Nitrogen Use Efficiency}

Rainfall use efficiency is a factor that indicates the productivity of an ecosystem. ${ }^{18}$ This depends on soil and vegetation condition and its dynamic status. ${ }^{31}$ The year $\mathrm{x}$ sludge treatment interaction for the combined analyses across years is mainly because of the variation in the rainfall (Table 1) as well as the sludge $\mathrm{N}$ content across years (Table 3). Nevertheless, annual rainfall use efficiency within a season increased as the sludge application rates doubled (Fig. 3). The significant improvement in annual rainfall use efficiency was because of the significant increase in hay yield per unit water used.

Generally, the RUE from this study was much higher than the ranges reported for weeping lovegrass (3.7-10 $\mathrm{kg} \mathrm{DM} \mathrm{ha}^{-1} \mathrm{yr}^{-1} \mathrm{~mm}^{-1}$ ) in Argentina. ${ }^{18}$ This is most probably because of higher water holding capacity and nutrient status of the soil from this study among other factors. 
In contrast to the RUE, the NUE decreased significantly with doubling of the sludge application rate for rates exceeding $8 \mathrm{Mg} \mathrm{ha}^{-1}$ during the 2004/05 and 2005/06 growing seasons and $4 \mathrm{Mg} \mathrm{ha}^{-1}$ in five of the eight years. This reduction is most probably attributed to the nutrient carryover effects from the previous years that resulted in higher total $\mathrm{N}$ availability for crop uptake in the years that followed. This could be clearly observed from the trends of NUE increment across years. Our results agree with Sigua ${ }^{9}$ who showed that increasing doses of sewage sludge did not proportionally improve soil nitrogen use efficiency. The low $\mathrm{N}$ use efficiency of the $16 \mathrm{Mg} \mathrm{ha}^{-1}$ sludge treatment indicate that a large fraction of the $\mathrm{N}$ added from sludge is stored in the soil profile or lost from the system through leaching and volatilization. ${ }^{16}$ In this study, however, a large portion of the $\mathrm{N}$ is stored in the soil profile because previous results from the same study site has already shown a significant build up $\mathrm{N}$ in the top $10 \mathrm{~cm}$ layer of the $16 \mathrm{Mg} \mathrm{ha}^{-1}$ sludge application rate compared with all other rates. ${ }^{16}$

Studies conducted by Gargano on the NUE of weeping lovegrass using inorganic commercial fertilizer as source of $\mathrm{N}$, showed that NUE was highest at lowest productivity levels. ${ }^{20}$ This is in contrast to our findings where NUE seemed to be influenced by $\mathrm{N}$ carry over effects at low application rates when using sludge as source of N. Therefore, although there was a clear decline in NUE with the doubling of sludge application rate, it was not because of the effect of salts but rather because of $\mathrm{N}$ carry over effects. 


\section{Trace Metal Uptake}

The uptake and/or bioavailability of trace metals, depends on several factors, the most important of which is $\mathrm{pH} .{ }^{32}$ Trace metal uptake by plants is a function of the metal, sludge/soil physiochemical properties and plant species. ${ }^{33}$ Sludge-borne trace elements are usually organically bound and less mobile compared with impurities in commercial inorganic fertilizers. Use of sewage sludge facilitates the biofortification of selenium through recycling of organic matter. ${ }^{32}$ This study revealed that the application of municipal sludge significantly increased the aboveground biomass concentration of certain metals such as $\mathrm{Cr}$ and $\mathrm{Zn}$. This is in contrast to the previous findings, which reported insignificant differences in trace metal uptake by Bermuda grass planted to a soil that received sludge for 10 years. ${ }^{34}$ This difference may be attributed to the relatively higher concentration of $\mathrm{Cr}\left(239 \mathrm{mg} \mathrm{kg}^{-1}\right)$ and $\mathrm{Zn}$ (2479 $\left.\mathrm{mg} \mathrm{kg}^{-1}\right)$ in the sludge used for our study compared to their $\left(\mathrm{Cr}=115 \mathrm{mg} \mathrm{kg}^{-1}\right.$; $\mathrm{Zn}=500 \mathrm{mg} \mathrm{kg}^{-1}$ ). The insignificant $\mathrm{Ni}, \mathrm{V}$, and Se uptake differences between treatments is in par with previous findings from USA. ${ }^{34}$ Other elements such as As and $\mathrm{Cd}$, however, did not show consistent trends across years. Generally the concentration of those trace metals under investigation was far lower than the reported domestic animals maximum tolerable dietary concentration as reported in NRC (2005). ${ }^{35}$

\section{CONCLUSION}

Results from the current study indicated that sludge application rates based on crop $\mathrm{N}$ requirements improved hay yield, CP content, NUE and WUE. In addition, 
application of municipal sludge, with low trace metal content, for weeping lovegrass hay production does not seem to cause significant uptake of trace elements to trigger animal health risk in the short to medium term. The pathological threat of products, obtained from animals feeding on pastures produced using sewage sludge, may require further investigations.

\section{ACKNOWLEDGEMENTS}

The authors wish to sincerely acknowledge Water Research Commission, East Rand Water Care Company and National Research Foundation of South Africa for funding this study.

\section{REFERENCES}

1 Cogger CG, Bary AI, Fransen SC, and Sullivan DM.. Seven years of biosolid versus inorganic nitrogen applications to Tall Fescue. J Environ Qual 30:21882194 (2001).

2 Shepherd MA, Factors affecting nitrate leaching from sewage sludges applied in a sandy soil in arable agriculture. Agric Ecosyst Environ 58:171-185 (1996).

3 Goldstein, N. State biosolids management update. Biocycle 38:62-66 (1997).

4 Kao P, Huang C, and Hseu Z, Response of microbial activities to heavy metals in a neutral loamy soil treated with biosolid. Chemosphere 64:63-70 (2005). 
5 Epstein E, Taylor JM, and Chaney RL, Effects of sewage sludge and sludge compost applied to soil and some soil physical and chemical properties. J Environ Qual 5:422-426 (1976).

6 Mininni G, and Santori M, Problems and perspectives of sludge utilization in agriculture. Agric Ecosyst Environ 18:291-311 (1987).

7 Navas A,Bermứdez F, and Machí J, Influence of sewage sludge application on physical and chemical properties of gypsisols. Geoderma 87:123-135 (1998).

8 Coker EG, Hall JE, Carlton-Smith CH, and Davis RD, Field investigations into the manorial value of liquid undigested sewage sludge when applied to grassland. J Agric Sci 109:479-494 (1987).

9 Sigua GC, Recycling biosolid and lake-dredged materials to pasture- based animal agriculture: Alternative nutrient sources for forage productivity and sustainability. A review, Sustainable Agric 29: 143-160 (2009).

10 Sullivan DM, Fransen SC, Cogger CG, and Bary AI, Biosolids and dairy manure as nitrogen sources for prairie grass on a poorly drained soil. J. Prod Agric 10:589-596 (1997).

11 Zebarth BJ, McDougall R, Neilsen G, and Neilsen D, Availability of nitrogen from municipal biosolids for dryland forage grass. Can J Plant Sci 80:575-58 (2000).

12 Herbel CH, Principles of intensive range improvements. J Range Manage 36:140144 (1983). 
13 Muyen, Z, Moore GA, and Wrigley RJ, Soil salinity and sodicity effects of wastewater irrigation in South East Australia. Agr Water Manage 99:33-41 (2011).

$14 \mathrm{Hu}$ Y, and Schmidhalter U, Drought and salinity: a comparison of their effects on mineral nutrition of plants. J Plant Nutr Soil Sci 168: $541-549$ (2005).

15 Snyman HG, and Herselman JE, Guidelines for the utilization and disposal of wastewater sludge, Volume 2: Requirements for the agricultural use of wastewater sludge. WRC Rep. TT 262/06. Water Research Commission, South Africa (2006).

16 Tesfamariam EH, Annadale JG, Steyn JM, Strirzaker RJ, and Mbakwe I, Municipal sludge as source of nitrogen and phosphorus in perennial pasture Eragrostis curvula production: Agronomic benefits and environmental impacts. Water SA 39:507-514 (2013).

17 Novoa R, and Loomis RS, Nitrogen and plant production. Plant Soil 58:117-204 (1981).

18 Guevara JC, Estevez OR, Stasi CR, and Le Houérou HN, The role of weeping lovegrass, Eragrostis curvula, in the rehabilitation of deteriorated arid and semiarid rangelands in Argentina. Arid Land Res Manage 19:125-146 (2005).

19 SAS Institute. The SAS system for Windows. SASInst. Cary, NC. U.S. (2011).

20 Gargano AO, Adúriz MA, Arelovich HM, and Amela MI, Forage yield and nutritive value of Eragrostis curvula and Digitaria eriantha in central-south semi-arid Argentina. Trop Grasslands 35:161-167 (2001). 
21 Dickinson EB, Hyam GFS, Breytenbach WAS, Metcalf HD, Basson WD, Williams FR, Plint AP, Smith HRH, Smith PJ, Van Vuuren PJ, Viljoen JH, Archibald KP, and Els JM, Kynoch pasture handbook. Kejafa knowledge works, Maanhaarrand, South Africa (2004).

22 Aravindhakshan SC, Epplin FM, and Raliaferro CM, Switchgrass, bermudagrass, flaccidgrass and lovegrass biomass yield response to nitrogen for single and double harvest. Biomass Bioenerg 35:308-319 (2011).

23 Haque M, Epplin F, and Taliaferro C, Nitrogen and harvest frequency effect on yield and cost for four perennial grasses. Agron J 101:1463-1469 (2009).

24 Meissner HH, Zacharias PJK, and O'Reagain PJ, Forage quality (feed value).In Eds N. Tainton, editors, Pasture management in South Africa. University of Natal Press, Pietermaritzburg, RSA. p. 60-88 (2000).

25 Strickland RW, Dry matter production, digestibility and mineral content of Eragrostis superba Peyr. and E. curvula (Schrad.) Nees. at Samford, south eastern Queensland. Trop Grasslands 7:233-241 (1973).

26 Luciani G, Sobanski M, Meier M, Polci P, Miranda R, and Echenique V, Weeping lovegrass yield and nutritive value provides an alternative to beef cattle feeding in semiarid environments of Argentina. Crop Sci 52:1955-1965 (2012).

27 Meissner H, Recent research on forage utilization by ruminant livestock in South Africa. Anim. Feed Sci Technol 69:103-119 (1997).

28 McMurphy WE, Denman CE, and Tucker BB, Fertilization of native grass and weeping lovegrass. Agron J 667:233-236 (1975). 
29 Taliaferro CM, Horn FP, Tucker BB, Totusek R and Morrison RD, Performance of three warm-season perennial grasses and a native range mixture as influenced by $\mathrm{N}$ and P fertilization. Agron J 67:289-292 (1975).

30 Masters RA and Britton CM, Ermelo weeping lovegrass response to clipping, fertilization and watering. J Range Manage 43:461-465 (1990).

31 Le Houérou HN, Rain use efficiency: A unifying concept in arid-land ecology. J Arid Environ 7: 213-247 (1984).

32 Garcia Moreno R, Burdock R, Díaz Álvarez MC, and Crawford JW, Managing the Selenium Content in Soils in Semiarid Environments through the Recycling of Organic Matter. Appl Environ Soil Scihttp://dx.doi.org/10.1155/2013/283468 (2013).

33 Kidd PS, Dominguez-Rodriguez MJ, Diez J and Monterroso C, Bioavailability and plant accumulation of heavy metals and phosphorus in agricultural soils amended by long-term application of sewage sludge. Chemosphere 66:1458-1467 (2017).

34 Gaskin JW, Brobst RB, Miller WP and Tollner EW, Long-term biosolids application effects on metal concentrations in soil and bermudagrass forage. $\mathbf{J}$ Environ Qual 32:146-152 (2003).

35 NRC. Mineral tolerance of domestic animals: second revised edition. National Research Council Subcommittee on mineral toxicity in animals and Committee on Minerals and Toxic Substances in Diets and Water for Animals. National Academies Press, Washington, DC., U.S. DOI: https://doi.org/10.17226/11309 (2005) 